\title{
Pseudomonas melanogena lizuka and Komagata 1963, a Later Subjective Synonym of Pseudomonas maltophilia Hugh and Ryschenkow 1960
}

\author{
K. KOMAGATA, EIKO YABUUCHI, Y. TAMAGAWA, and A. OHYAMA
}

Institute of Applied Microbiology, University of Tokyo, Bunkyo-ku, Tokyo, Japan; Kansai Medical School, Department of Microbiology, Moriguchi, Osaka, Japan; and Central Research Laboratories, Ajinomoto Co., Inc., Kawasaki, Japan

\begin{abstract}
Strain IAM 1554 (ATCC 17806) is herein designated as the type strain of Pseudomonas melanogena lizuka and Komagata 1963 and compared with ATCC 13637, the type strain of Pseudomonas maltophilia Hugh and Ryschenkow 1960. The three additional strains used in the original description of $P$. melanogena and five strains of $P$. maltophilia originally identified as Pseudomonas alcaligenes are also studied. The morphological and physiological attributes and deoxyribonucleic acid base compositions of the 10 strains are sufficiently similar so as to place these strains in a single species, the correct name of which is $P$. maltophilia. The name $P$. melanogena is reduced to being a junior synonym of $P$. maltophilia.
\end{abstract}

Pseudomonas melanogenum (sic) (the specific epithet is here corrected to melanogena to agree with the feminine gender of the generic name Pseudomonas) was named and described by Iizuka and Komagata (8) in 1963 on the basis of observations of four strains (YF-3, YF-6, YF-8, and YF-10) isolated from Japanese rice paddies. These strains produced yellow pigment and a brown coloration on nutrient agar supplemented with tyrosine and were unable to grow on glutamate agar. Although a type strain was not designated for this species when it was named and described, strain YF-3 was deposited in the American Type Culture Collection (ATCC), Rockville, Md., as the type strain; it carries the ATCC accession number 17806 (1). This strain is listed in the ATCC Catalogue of Strains (1) as the type strain; however, culture collection catalogues do not constitute effective publication, and so strain YF-3 is here designated as the type strain of $P$. melanogena. $P$. maltophilia was named and described by Hugh and Ryschenkow in 1960 (Bacteriol. Proc., p. 78, 1960), and in the following year these authors designated ATCC 13637 as the type strain (7). According to Buchanan et al. (2), P. maltophilia is a validly published and legitimate name. Komagata (12) and Iizuka and Komagata $(9,10)$ isolated from oil brine five strains of Pseudomonas that did not produce acid from glucose and identified them as strains of Pseudomonas alcaligenes.
Hugh and Leifson (6) reidentified these five strains as $P$. maltophilia, and lizuka and Komagata (11) agreed with this conclusion.

A comparative study of the four original strains of $P$. melanogena and six strains of $P$. maltophilia, including the type strain, was undertaken to determine the taxonomic relationship between the two species, since both exhibit deoxyribonuclease and nucleoside phosphotransferase activities, which are only rarely observed in Pseudomonas species.

\section{MATERIALS AND METHODS}

Bacterial strains. The type strain of $P$. maltophilia, the five strains of $P$. maltophilia identified initially as $P$. alcaligenes $(9,10,12)$, the strain designated above as the type strain of $P$. melanogena, and the three other strains on which the original description of $P$. melanogena was based were studied. The histories and corresponding numbers of these 10 strains are listed in Table 1.

Methods. The characteristics of the strains were determined by methods described previously $(9,10$, $13,18)$.

\section{RESULTS AND DISCUSSION}

The 10 strains studied contained gram-negative, asporogenous rods that were actively motile with polar flagella. Although the original 
TABLE 1. Strain designations, sources of isolation, and corresponding numbers of strains identified here as Pseudomonas maltophilia

\begin{tabular}{|c|c|c|c|c|c|c|c|c|c|}
\hline \multirow{2}{*}{$\begin{array}{c}\text { Original } \\
\text { name }\end{array}$} & \multirow{2}{*}{$\begin{array}{l}\text { Strain desig- } \\
\text { nation of } \\
\text { lizuka and } \\
\text { Komagata }\end{array}$} & \multicolumn{5}{|c|}{ Other strain designations ${ }^{a}$} & \multirow[b]{2}{*}{ Status } & \multirow{2}{*}{$\begin{array}{c}\text { Source of } \\
\text { isolation }\end{array}$} & \multirow{2}{*}{$\begin{array}{l}\text { Refer- } \\
\text { ence }\end{array}$} \\
\hline & & $\mathrm{AJ}$ & ATCC & IAM & $\mathrm{KM}$ & $\mathrm{RH}$ & & & \\
\hline P. maltophilia & & 2082 & 13637 & & 418 & 1168 & Type & & 6 \\
\hline P. melanogena & YF-3 & 2220 & 17806 & 1554 & 318 & 2880 & Type & Rice paddy & 8 \\
\hline P. melanogena ..... & YF-6 & 2221 & 17807 & 1556 & 798 & & & Rice paddy & 8 \\
\hline P. melanogena ...... & YF-8 & 2222 & 17808 & 1577 & 799 & & & Rice paddy & 8 \\
\hline P. melanogena ...... & $\mathrm{YF}-10$ & 2223 & 14535 & 1588 & 800 & & & Rice paddy & 8 \\
\hline P. alcaligenes ....... & P-1 & 2273 & & 1396 & 412 & 1875 & & Oil brine & 6,11 \\
\hline$P$. alcaligenes . . . . . . & P-7 & 2277 & & 1450 & 413 & 1876 & & Oil brine & 6,11 \\
\hline P. alcaligenes. & P-7-2 & 2275 & & 1425 & 414 & 1877 & & Oil brine & 6,11 \\
\hline$P$. alcaligenes. & P-19 & 2274 & & 1411 & 415 & 1878 & & Oil brine & 6,11 \\
\hline P. alcaligenes. & P-31-2 & 2276 & & 1438 & 416 & 1879 & & Oil brine & 6,11 \\
\hline
\end{tabular}

${ }^{a}$ AJ, Central Research Laboratories, Ajinomoto Co., Inc., Kawasaki, Japan; ATCC, American Type Culture Collection, Rockville, Md.; IAM, Institute of Applied Microbiology, University of Tokyo, Tokyo, Japan; KM, Kansai Medical School Culture Collection, Osaka, Japan; RH, Rudolph Hugh, George Washington University, Washington, D.C.

description of $P$. melanogena (8) indicated that all four strains studied were motile with a single, polar flagellum, reexamination revealed cells in each strain with a tuft of polar flagella. Cells of the type strains of $P$. maltophilia and $P$. melanogena, each with a tuft of polar flagella, are shown in Fig. 1 and 2, respectively. The 10 strains grew well aerobically on nutrient agar, Leifson deoxycholate agar, and Christensen citrate agar, whereas growth on SalmonellaShigella and nalidixic acid-cetrimide agars was variable from strain to strain. Growth was not detected in a chemically defined liquid medium containing glucose as the sole cource of carbon and energy and ammonium ion as the sole source of nitrogen, on glutamate agar (12), or on Simmons citrate agar; growth was observed when these media were supplemented with L-methionine $(50 \mathrm{mg} / \mathrm{liter})$. The requirement for methionine by $P$. maltophilia was first reported by lizuka and Komagata (11) and later confirmed on 23 strains of this species by Stanier et al. (17). All of the strains hydrolyzed gelatin, Tween 80, and deoxyribonucleic acid (DNA), and a green discoloration of the erythrocytes surrounding dense growth was observed on rabbit blood agar. A brown coloration developed in nutrient agar supplemented with $0.1 \%$ tyrosine. Growth on heart infusion agar and other media appeared lemon yellow. Lysine decarboxylase and phenylalanine deaminase activities were variable. All of the strains except YF-10 produced nitrite from nitrate. None of the strains grew anaerobi-

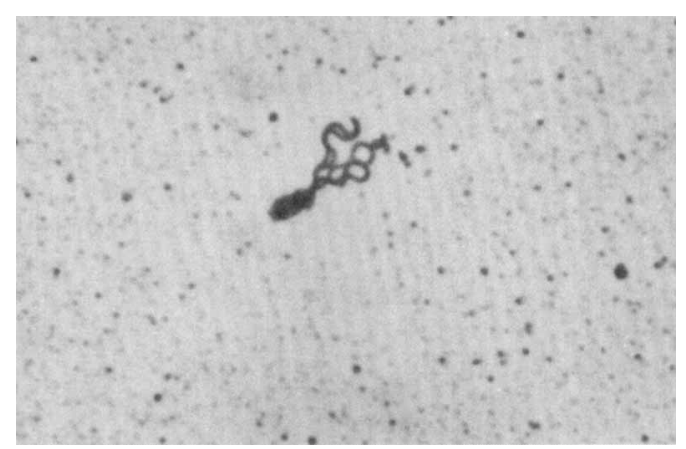

FIG. 1. Pseudomonas maltophilia ATCC 13637 (type strain) showing a tuft of polar flagella. Leifson flagella stain. $\times 1,500$.

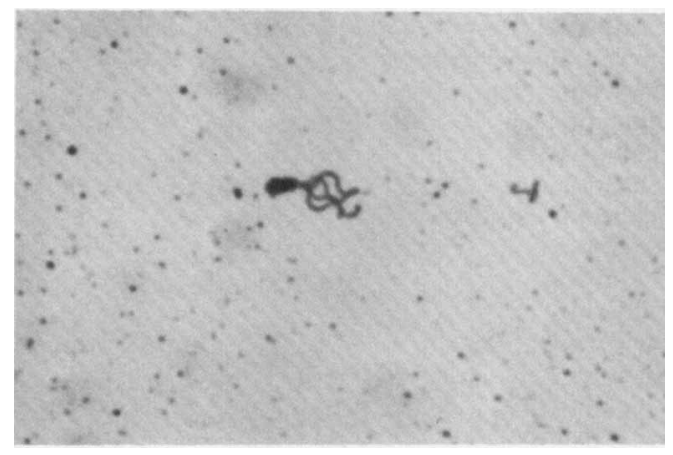

FIG. 2. Pseudomonas melanogena IAM 1554 (type strain) showing a tuft of polar flagella. Leifson flagella stain. $\times 1,500$. 
cally by nitrate respiration. All grew in brain heart infusion (BHI) broth containing 3\% sodium chloride. Only the type strain of 2 . maltophilia grew at $41 \mathrm{C}$ in BHI broth. Three strains (YF-8, YF-10, and $\mathrm{P}-7$ ) produced a feeble oxidase reaction, but the results were recorded as negative because the reaction was slow and weak. Stanier et al. (17) reported a negative oxidase reaction for 23 strains of $P$. maltophilia, whereas Snell et al. (16) observed that the oxidase reaction of $P$. maltophilia was variable. None of the strains grew in BHI broth adjusted to $\mathrm{pH}$ 4.5. Erythrocytes were not hemolyzed around discrete colonies on rabbit blood agar. 2-Ketogluconate was not produced from gluconate. Arginine dihydrolase, ornithine decarboxylase, and urease were not produced. A water-soluble, fluorescent pigment was not produced on Pseudomonas F agar (Difco), but the medium slowly turned brownish after several days of incubation at room temperature. Iizuka and Komagata $(8,11)$ reported that their strains of $P$. alcaligenes, which were later reidentified as $P$. maltophilia, and $P$. melanogena produced hydrogen sulfide from nutrient broth supplemented with $0.05 \%$ cysteine when tested with lead acetate paper. Hydrogen sulfide was also detected by lead acetate paper suspended over an inoculated Kligler iron agar slant but not by blackening of the butt. All of the strains produced acid oxidatively from glucose, fructose, mannose, maltose, and cellobiose in OF medium (Difco 0688); a weak acid reaction was produced from sucrose, lactose, melibiose, and trehalose. Acid production from D-ribose, xylose, raffinose, salicin, and ethanol varied from strain to strain. No acid was produced from L-arabinose, D-arabinose, galactose, rhamnose, melezitose, glycerol, dulcitol, inositol, adonitol, sorbitol, mannitol, or salicin. lizuka and Komagata (8) reported that $P$. melanogena produced acid from glucose in an open tube of OF medium. Hugh and Ryschenkow (7) first reported that $P$. maltophilia did not produce acid from glucose when they used the oxidative fermentative methods of Hugh and Leifson (5) and Leifson (14), but later Hugh and Leifson (6) reported that in OF medium (Difco 0688) the type strain of $P$. maltophilia produced acid promptly from fructose, maltose, and mannose and slowly from glucose. The characteristic of the 10 strains studied are similar to those of $P$. maltophilia as given previously $(3,4,7,11)$. From the results we obtained and from those reported by others, $P$. maltophilia does produce acid oxidatively from glucose. Production of the 5 '-nucleotide by the nucleoside phosphotransferase of $P$. melanogena was reported by Mitsugi et al. (15), and all of the 10 strains studied here also produced the $5^{\prime}$-nucleotide. The antibiotic susceptibility patterns of the 10 strains are shown in Table 2. All were susceptible to nalidixic acid and not susceptible to novobiocin. The DNA base compositions of the five strains studied, including the two type strains, are in the range of 65.1 to $66.5 \%$ guanine plus cytosine (Table 3 ). Sufficient differences were

TABLE 2. Antibiotic-susceptibility patterns of the strains studied

\begin{tabular}{|c|c|c|c|c|c|c|c|c|c|c|}
\hline \multirow[b]{2}{*}{ Antibiotic } & \multicolumn{10}{|c|}{ Susceptibility of strain ${ }^{a}$} \\
\hline & $\begin{array}{l}\text { ATCC } 13637 \\
\text { (Type strain of } \\
\text { P. maltophilia) }\end{array}$ & $\begin{array}{c}\text { YF-3 (Type } \\
\text { strain of } \\
\text { P. melanogena) }\end{array}$ & YF-6 & YF-8 & YF-10 & P-1 & P-7 & P-7-2 & P-19 & P-31-2 \\
\hline Ampicillin ..... & - & +++ & - & - & - & ++ & - & - & - & - \\
\hline Chlorampheni- & ++ & +++ & $+t$ & ++ & ++ & + & + & + & + & + \\
\hline Colistin $\ldots \ldots \ldots$ & ++ & +++ & ++ & +++ & ++ & $+t$ & ++ & ++ & ++ & $\begin{array}{c}+ \\
++\end{array}$ \\
\hline Erythromy cin $\ldots$ & - & + & - & - & - & - & - & - & - & - \\
\hline Gentamicin .... & + & ++ & + & - & + & + & - & - & + & - \\
\hline Kanamycin .... & ++ & - & - & - & - & - & - & - & - & - \\
\hline $\begin{array}{l}\text { Nalidixic } \\
\quad \text { acid ..... }\end{array}$ & ++ & +++ & +++ & + & +++ & t+ & +++ & +++ & ++ & ++ \\
\hline Novobiocin $\ldots .$. & - & - & - & - & - & - & - & - & - & - \\
\hline Penicillin ...... & - & ++ & - & - & - & - & - & - & - & - \\
\hline Polymyxin B .... & +++ & +++ & + & + & ++ & ++ & + & ++ & ++ & ++ \\
\hline Streptomycin .... & - & - & - & - & - & - & - & - & - & - \\
\hline Tetramycin .... & ++ & +++ & ++ & - & ++ & + & ++ & + & + & + \\
\hline
\end{tabular}

$a_{+,++,+++}$, Sensitive; - , insensitive. The degree of susceptibility to the antibiotic disk is expressed according to the manufacturer's statement (18). 
TABLE 3. Characteristics of the strains studied

\begin{tabular}{|c|c|c|c|c|c|c|c|c|c|c|}
\hline \multirow[b]{2}{*}{ Characteristics $^{a}$} & \multicolumn{10}{|c|}{ Reaction of strains $s^{b}$} \\
\hline & $\begin{array}{c}\text { ATCC } 13637 \\
\text { (Type strain } \\
\text { of } P . \text { mal. } \\
\text { tophilia) } \\
\end{array}$ & $\begin{array}{c}\text { YF-3 (Type } \\
\text { strain of } \\
\text { P. melano- } \\
\text { gena) }\end{array}$ & YF-6 & YF-8 & YF-10 & P-1 & $\mathrm{P}-7$ & P-7-2 & P-19 & P-31-2 \\
\hline Gram-negative rods & + & + & + & + & + & + & + & + & + & + \\
\hline Motility & + & + & + & + & + & + & + & + & + & + \\
\hline $\begin{array}{l}\text { Polar tuft of fla- } \\
\text { gella }\end{array}$ & + & + & + & + & + & + & + & + & + & + \\
\hline Growth on LD agar & + & + & + & + & + & + & + & + & + & + \\
\hline Growth on SS agar & + & - & + & $\begin{array}{l}+ \\
\text { wk } 3\end{array}$ & - & - & $+_{3}$ & - & - & $+{ }_{2}$ \\
\hline Growth on NAC agar & - & - & - & - & - & $t_{2}$ & $+t_{2}$ & - & $+{ }_{2}$ & $+_{2}$ \\
\hline $\begin{array}{l}\text { Growth in BHI at } \\
\quad 41 \mathrm{C}\end{array}$ & $t_{2}$ & - & - & - & - & - & - & - & - & - \\
\hline $\begin{array}{l}\text { Hemolysis, rabbit } \\
\text { blood }\end{array}$ & - & - & - & - & - & - & - & - & - & - \\
\hline $\begin{array}{l}\text { Green discoloration, } \\
\text { rabbit blood }\end{array}$ & + & + & + & + & $t_{2}$ & + & + & + & + & + \\
\hline $\mathrm{H}_{2} \mathrm{~S}$, Kligler butt & - & - & - & - & - & - & - & - & - & - \\
\hline $\begin{array}{l}\mathrm{H}_{2} \mathrm{~S} \text {, Kligler lead } \\
\text { acetate paper }\end{array}$ & + & $t_{2}$ & + & $t_{2}$ & $t_{2}$ & + & + & $t_{2}$ & $t_{2}$ & $t_{2}$ \\
\hline $\begin{array}{l}\text { Hydrolysis of gela- } \\
\text { tin }\end{array}$ & + & $t_{3}$ & + & + & + & + & + & + & + & $+_{2}$ \\
\hline $\begin{array}{l}\text { Hydrolysis of } \\
\text { Tween } 80\end{array}$ & + & + & + & + & + & + & + & + & + & + \\
\hline Deoxyribonuclease & + & + & + & + & + & + & + & + & + & + \\
\hline 2-Ketogluconate & - & NG & - & NG & NG & - & - & NG & - & - \\
\hline Malonate & $t_{2}$ & $t_{2}$ & $t_{2}$ & $t_{2}$ & $t_{2}$ & $t_{2}$ & $t_{2}$ & $t_{3}$ & $+_{2}$ & $t_{2}$ \\
\hline Citrate, Simmons & - & - & - & - & - & - & - & - & - & - \\
\hline $\begin{array}{l}\text { Citrate, Simmons } \\
\text { with methionine }\end{array}$ & + & + & + & + & + & + & + & + & + & + \\
\hline Citrate, Christensen & + & + & + & + & + & + & + & + & + & + \\
\hline $\begin{array}{l}\text { Nitrate reduction } \\
\text { to nitrite }\end{array}$ & + & + & + & + & - & + & + & + & + & + \\
\hline $\begin{array}{l}\text { Nitrate respiration } \\
\text { Acid from: }\end{array}$ & - & - & - & - & - & - & - & - & - & - \\
\hline Glucose, aerobically & $+t_{3}$ & $+_{2}$ & $+_{4}$ & + & $t_{4}$ & + & + & $t_{3}$ & $t_{3}$ & + \\
\hline $\begin{array}{l}\text { Glucose, anaerobic- } \\
\text { ally }\end{array}$ & - & - & - & - & - & - & - & - & - & - \\
\hline Ethanol & - & $t_{5}$ & $t_{3}$ & $t_{3}$ & ++ & - & - & - & - & - \\
\hline Glycerol & - & - & - & - & - & - & - & - & - & - \\
\hline D-Arabinose & - & - & - & - & - & - & - & - & - & - \\
\hline L-Arabinose & - & - & - & - & - & - & - & - & - & - \\
\hline D-Ribose & - & - & - & - & - & - & - & - & - & - \\
\hline Xylose & - & $\begin{array}{l}+ \\
\text { wk } 10\end{array}$ & $\begin{array}{l}+ \\
\text { wk } 6\end{array}$ & $\begin{array}{l}+ \\
\text { wk } 4\end{array}$ & $\begin{array}{l}+ \\
\text { wk } 3\end{array}$ & - & - & - & - & - \\
\hline Rhamnose & - & - & - & - & - & - & - & - & - & - \\
\hline Mannose & + & $t_{2}$ & + & + & + & + & + & + & + & + \\
\hline Fructose & + & $t_{2}$ & + & + & + & + & + & + & + & + \\
\hline Galactose & - & - & - & - & - & - & - & - & - & - \\
\hline Cellobiose & $t_{3}$ & $\begin{array}{l}+ \\
\text { wk } 2\end{array}$ & + & $\begin{array}{l}+ \\
\text { wk }\end{array}$ & $\begin{array}{l}+ \\
\text { wk } 4\end{array}$ & + & + & $t_{3}$ & $t_{3}$ & + \\
\hline Lactose & $t_{4}$ & $\begin{array}{l}+ \\
\text { wk } 4 \\
\end{array}$ & + & $\begin{array}{l}+ \\
\text { wk } 4 \\
\end{array}$ & $\begin{array}{l}+ \\
\text { wk } 4 \\
\end{array}$ & $\begin{array}{l}+ \\
\text { wk }\end{array}$ & $t_{3}$ & + & $\begin{array}{l}+ \\
\text { wk } 3 \\
\end{array}$ & $\begin{array}{l}+ \\
\text { wk } 4 \\
\end{array}$ \\
\hline
\end{tabular}


TABLE 3.-Continued

\begin{tabular}{|c|c|c|c|c|c|c|c|c|c|c|}
\hline Characteristics $^{a}$ & $\begin{array}{c}\text { ATCC } 13637 \\
\text { (Type strain } \\
\text { of } P \text { mal- } \\
\text { tophilia) }\end{array}$ & $\begin{array}{l}\text { YF-3 (Type } \\
\text { strain of } \\
\text { P. melano- } \\
\text { gena) }\end{array}$ & YF-6 & YF-8 & YF-10 & P-1 & P-7 & P-7-2 & P-19 & P-31-2 \\
\hline Maltose & + & $t_{2}$ & + & + & + & + & + & + & + & + \\
\hline Sucrose & & + & + & $t_{4}$ & & + & + & + & + & + \\
\hline & $\begin{array}{l}\text { wk } 4 \\
+\end{array}$ & $\begin{array}{l}\text { wk } 10 \\
t_{4}\end{array}$ & $\begin{array}{l}\text { wk } 6 \\
+\end{array}$ & + & $\begin{array}{l}\text { wk } 3 \\
+\end{array}$ & $\begin{array}{l}\text { wk } \\
+\end{array}$ & $\begin{array}{l}\text { wk } 3 \\
+\end{array}$ & $\begin{array}{l}\text { wk } 3 \\
+\end{array}$ & $\begin{array}{l}\text { wk } 4 \\
+\end{array}$ & $\begin{array}{l}\text { wk } 4 \\
+\end{array}$ \\
\hline If enarose & wk 4 & & wk 6 & wk 4 & wk 3 & wk & wk 4 & wk 6 & wk 4 & wk 4 \\
\hline Melibiose & $t_{4}$ & $\begin{array}{l}+ \\
\text { wk } 5\end{array}$ & $\begin{array}{l}+ \\
\text { wk } 4\end{array}$ & $\begin{array}{l}+ \\
\text { wk } 4\end{array}$ & $t_{4}$ & + & $t_{3}$ & + & ++ & $\begin{array}{l}+ \\
\text { wk } 6\end{array}$ \\
\hline Raffinose & $\stackrel{+}{\text { wk } 4}$ & $\begin{array}{l}+ \\
\text { wk } 10\end{array}$ & - & $\begin{array}{l}+ \\
\text { wk } 4\end{array}$ & $\begin{array}{l}+ \\
\text { wk } 4\end{array}$ & $t_{3}$ & - & - & - & + \\
\hline Melezitose & - & - & - & - & - & - & - & - & - & - \\
\hline Adonitol & - & - & - & - & - & - & - & - & - & - \\
\hline Dulcitol & - & - & - & - & - & - & - & - & - & - \\
\hline Inositol & - & - & - & - & - & - & - & - & - & - \\
\hline Mannitol & - & - & - & - & - & - & - & - & - & - \\
\hline Sorbitol & - & - & - & - & - & - & - & - & - & - \\
\hline Inulin & - & - & - & - & - & - & - & - & - & - \\
\hline Salicin & - & - & - & - & - & - & - & - & - & - \\
\hline $\begin{array}{l}\text { OF basal medium } \\
\text { control, blue }\end{array}$ & + & + & + & + & + & + & + & + & + & + \\
\hline Carlquist, ninhydrin & + & + & + & + & + & + & - & - & + & + \\
\hline $\begin{array}{l}\text { L-Lysine decarbox- } \\
\text { ylase, M } \phi \text { ller }\end{array}$ & - & $t_{2}$ & $t_{2}$ & - & $t_{2}$ & - & - & - & $t_{2}$ & $t_{2}$ \\
\hline $\begin{array}{l}\text { L-Arginine dihydro- } \\
\text { lase, M,pller }\end{array}$ & - & - & - & - & - & - & - & - & - & - \\
\hline $\begin{array}{l}\text { L-Ornithine decar- } \\
\text { boxylase, M } \phi \text { ller }\end{array}$ & - & - & - & - & - & - & - & - & - & - \\
\hline Oxidase & - & - & - & - & - & - & - & - & - & - \\
\hline Catalase & + & + & + & + & + & + & + & + & + & + \\
\hline Urease & - & - & - & - & - & - & - & - & - & - \\
\hline $\begin{array}{l}\text { Phenylalanine deamin- } \\
\text { ase }\end{array}$ & + & - & - & - & - & + & - & - & - & - \\
\hline $\begin{array}{l}\text { Growth in } \mathrm{BHI} \text { con- } \\
\text { taining } 3 \% \mathrm{NaCl}\end{array}$ & + & + & + & $t_{2}$ & $+_{2}$ & + & + & + & + & + \\
\hline $\begin{array}{l}\% \text { Guanine plus } \\
\text { cytosine }\end{array}$ & 65.1 & 65.2 & NT & NT & 66.3 & 66.5 & 66.5 & NT & NT & NT \\
\hline
\end{tabular}

${ }^{a}$ LD, Leifson deoxycholate agar; SS, Salmonella-Shigella agar; NAC, nalidixic acid-cetrimide agar; BHI, brain heart infusion.

$b+$, Positive reaction on the first day. Subscripts indicate the day the test became positive. -, Negative reaction; wk, weak reaction; NG, No growth; NT, not tested.

not detected among the guanine plus cytosine ratios of the five strains examined.

As is evident from the data presented in Tables 2 and 3 , there are only a few slight differences between the type strains of $P$. maltophilia Hugh and Ryschenkow 1960 and $P$. melanogena lizuka and Komagata 1963. Therefore, we regard these two names as subjective synonyms. $P$. maltophilia, being the earlier of the two names, has priority and is therefore the correct name of this species; $P$. melanogena becomes a junior synonym of $P$. maltophilia. The reidentification as $P$. maltophilia of several strains previously labeled $P$. alcaligenes $(9,10$, 12 ) is confirmed.

\section{LITERATURE CITED}

1. American Type Culture Collection. 1972. Catalogue of strains, 10th ed., p. 72. American Type Culture Collection, Rockville, Md.

2. Buchanan, R. E., J. G. Holt, and E. F. Lessel. 1966. Index Bergeyana, p. 873. The Williams \& Wilkins Co., Baltimore.

3. Gilardi, G. L. 1969. Pseudomonas maltophilia infection in man. Amer. J. Clin. Pathol. 51:58-61.

4. Hugh, R. 1970. Pseudomonas and Aeromonas, p. 
175-190. In J. E. Blair, E. H. Lennette, and J. P. Truant (ed.), Manual of clinical microbiology. American Society for Microbiology, Bethesda, Maryland.

5. Hugh. R., and E. Leifson. 1953. The taxonomic significance of fermentative versus oxidative metabolism of carbohydrates of various gram-negative bacteria. J. Bacteriol. 66:24-26.

6. Hugh. R., and E. Leifson. 1963. A description of the type strain of Pseudomonas maltophilia. Int. Bull. Bacteriol. Nomencl. Taxon. 13:133-138.

7. Hugh. R., and E. Ryschenkow. 1961. Pseudomonas maltophilia, an Alcaligenes-like species. J. Gen. Microbiol. 26:123-132.

8. Iizuka, H., and K. Komagata. 1963. Pseudomonas isolated from rice, with special reference to the taxonomic study of chromogenic group of genus Pseudomonas. (On the studies of microorganisms of cereal grain, Part III). J. Agr. Chem. Soc. Jap. 37:71-76.

9. lizuka, H., and K. Komagata. 1963. An attempt at grouping of the genus Pseudomonas. J. Gen. Appl. Microbiol. 9:73-82.

10. Iizuka, H., and K. Komagata. 1963. Taxonomy of the genus Pseudomonas with special reference to their modes of metabolism of carbon compounds. J. Gen. Appl. Microbiol. 9:83-95.

11. Iizuka, H., and K. Komagata. 1964. Microbiological studies on petroleum and natural gas. I.
Determination of hydrocarbon-utilizing bacteria. J. Gen. Appl. Microbiol. 10:207-221.

12. Komagata, K. 1961. Differentiation of genus Pseudomonas and related aerobic bacteria. J. Gen. Appl. Microbiol. 7:282-299.

13. Komagata, K., and Y. Tamagawa. 1966. Nucleoside phosphotransferase test as an aid to differentiation of Serratia marcescens from related bacteria. J. Gen. Appl. Microbiol. 12:191-193.

14. Leifson, E. 1958. Identification of Pseudomonas, Alcaligenes and related bacteria. Zentrabl. Bakteriol. Parasitenk. Infektionskr. Hyg. Abt. Orig. 173:487-488.

15. Mitsugi, K., K. Komagata, M. Takahashi, and H. Katagiri. 1964. Bacterial synthesis of nucleotide. II. Distribution of nucleoside phosphotransferases in bacteria. Agr. Biol. Chem. 28:586-600.

16. Snell, J. J., L. R. Hill, S. P. Lapage, and M. A. Curtis. 1972. Identification of Pseudomonas cepacia Burkholder and its synonymy with Pseudomonas kingii Jonsson. Int. J. Syst. Bacteriol. 22:127-138.

17. Stanier, R. Y., N. J. Palleroni, and M. Doudoroff. 1966. The aerobic pseudomonads: a taxonomic study. J. Gen. Microbiol. 43:159-271.

18. Yabuuchi, E., and A. Ohyama. 1972. Characterization of "pyomelanine"-producing strains of Pseudomonas aeruginosa. Int. J. Syst. Bacteriol. 22:53-64. 